\title{
Success in Israeli High-Tech Start-Ups; Critical Factors and Process
}

\section{Schaul Chorev, Alistair R. Anderson*,}

Charles P. Skene Centre for Entrepreneurship, Aberdeen Business School, The Robert Gordon University, Garthdee Road, Aberdeen AB10 7QE, Scotland, UK

Address for correspondence.

\author{
Alistair R. Anderson \\ Charles P. Skene Centre for Entrepreneurship \\ Aberdeen Business School \\ The Robert Gordon University \\ Garthdee Road \\ Aberdeen AB10 7QE \\ Scotland UK \\ Email: a.r.anderson@rgu.ac.uk
}

Telephone: +44 (0)1224 263883

Fax: +44 (0)1224 263870 


\title{
Success in Israeli High-Tech Start-Ups; Critical Factors and Process
}

\begin{abstract}
This paper develops a model of the factors deemed critical for success in high-tech new ventures in Israel. Israel presents an interesting forum, geographically distant from main markets but richly endowed with human capital, new high-tech ventures are seen as an essential element of the economy. Yet, despite its importance, high-tech is characterised by risk and challenge. Consequently a model which draws on the experience of success and failures should be valuable. Our multi stage methodology enrolled the wisdom and experience of founders, managers and financiers of high-tech businesses to identify and categorise the importance of the factors and the role played by these factors. We found that success factors could be grouped as critical or as important. The first group categorised the idea, strategy, the core team's commitment, expertise and marketing as critical. Important factors were deemed to be management, customer relationships and research and development. The least important factors proved to be those external to the firm, the economy, politics and the general business environment. Overall the study emphasised that the attitudes and abilities of the core team were paramount. Although the model is based on the Israeli experience, many of the aspects are global. Consequently the study may have broad applicability.
\end{abstract}

Keywords: high-tech, start-up, success factors, Israel 


\section{Introduction}

Whilst the importance of new business for economic development is widely acknowledged, the role of new exporting high-tech business in Israel is seen as vital. Israel is small and geographically isolated from the main markets, suffers from security difficulties, but fosters a culture which promotes knowledge rich new technologies. Thus, new ventures with leading edge technologies and prospects of high growth and profitability offer a means to achieve the national goal of economical independence. Internationally however, the high-technology sector has recently suffered badly from the bursting of the dot.com bubble and the crash of NASDAQ. Prior to the collapse, the remarkable enthusiasm for new high-technology ventures lead to quite idealistic expectations about the profitability and sustainability of many of these new companies. A characteristic of companies formed during the overheated period was the elevation of ideas over substance and in particular, the lack of a sound business practices. Consequently it became progressively more difficult to establish, both in Israel and elsewhere, successful new high-technology companies.

In addition to the negative climate for new businesses, all new high-technology companies also face general problems in their liability of newness and particular problems associated with creating new products employing high-technology. The technologies are often developing; applications may be unclear and the markets not yet established. Nonetheless, there is recognition about the potential value of these hightechnology companies and some evidence of their gradual re-emergence under difficult circumstances. To aid the sustainability of this re-emergence, this study addresses the issue of viable business models which could enhance the prospects of success. Such a model of best practices, if properly grounded in the experiences of both successful and 
unsuccessful entrepreneurs, may provide a template to guide the formation and operation of new and growing high-tech companies. The contribution of this paper is twofold, first to collate the experiences of practitioners and secondly, to synthesise these into a model which identifies factors critical for success, and factors which are important, but not deemed essential and the roles they play in shaping success.

In this way this study captures the implicit knowledge embedded in the experiences of entrepreneurs and others who are, or have been, engaged in the realities of high-tech venture creation. It categorises and synthesises this material and by analysis, establishes a practical model specifying the factors and their criteria seen to be critical for improving the success of high-technology new ventures. We developed a multi stage study, consisting of multiple interviews to develop a model, testing and refining by pilot and a final survey. The nature of this study thus provides empirical evidence about the factors deemed necessary for successful high-tech venturing in Israel. The paper begins by considering the role of high-tech ventures for economic growth generally and in Israel in particular. We then explain our methodology which builds upon the existing literature. Key factors and their roles are identified. From this we present our initial findings as a tentative model which we operationalised in our pilot study. Our revised questionnaire was completed by some 80 experts and finally refined in a Delphi review, from these data we arrive at our final model.

\section{High-tech's contribution to economic growth}

Although defining high-technology industries has been the subject of debate, (Oakey, Rothwell and Cooper, 1988) a broad definition of a high-tech business is one whose 
business activities are heavily dependent upon innovation in science and technology (Medcof, 1999). The characteristics of high-tech include; they invest more heavily in R\&D activities than the national average; employ a higher percentage of engineers and scientists among their staff; offer innovative and technologically advanced products; are dynamic in nature and have short product development cycles (Oakey et al., 1988; Reeble, 1990, Covin and Slevin, 1991). Thus these Schumpertian perspectives indicate a key role for new high-technology companies. In Israel, Cohen (2005) argues that the Israeli high-tech industry is characterized by a high added value for the products it manufactures and a high rate of per employee output, more than twice the average posted by other industrial sectors. Traston et al. (2002) foresee a bright future for Israeli high-tech. Indeed, Cohen claims that the course of Israel's economic growth for the coming years will continue to be determined by the future of this industry.

\section{High-tech in the Israeli context}

A number of authors have commented on the recent dramatic changes in the Israeli economy, (Dvir and Tishler, 1999; Lerner and Avrahami, 1999; Azulay, Lerner and Tishler, 2000; Israeli Ministry of finance-International Division, 2003; Israeli Ministry of Finance - Economic and Research Department, 2003). These can be summarized as follows;

- The Israeli market has opened up to foreign competition and international investments;

- A considerable wave of immigration, primarily from Russia, with many educated people in the fields of science and technology has been absorbed;

- Government and private support in know-how infrastructure has increased; 
- Shrinkage of the defense industry, which had been the main driver of the Israeli high-tech industry;

- Education levels have continued to improve;

- Changing lifestyle of the young generation and the computer era have attracted many youngsters into computer science, electronics and IT fields;

- The high-tech industry has raised more capital than any other sector in Israel.

In consequence, the Israeli technological market is now developed and diverse. Hightech is the major driver of the Israeli economy, emphasised by a growth rate which is the highest of all Israeli industrial sectors. During the first half of 2000, high-tech growth rate was $12 \%$, while the conventional industry growth rate was only $2 \%$ (Haaretz newspaper, 29.6.00). High-tech contributes $75 \%$ of the growth in Israeli GNP and 36\% of GNP (Israel Central Bureau of Statistics - ICBS, 2001). In human capital terms, Business Week (3/2/97) reports that Israel has a high proportion of scientists and engineers in the population, with approximately 130 scientists and engineers for every 10,000 workers. This compares with 80 and 75 in the U.S. and Japan, respectively. At $3.5 \%$, Israel has the greatest $\mathrm{R} \& \mathrm{D}$ expenditure in the world as a percentage of GDP (Traston et al., 2002) and the highest number of start-ups in the world in relation to the population size.

Perhaps the most striking of indicators of the substantial role of high-tech is the international comparison of venture capital investment. Figure 1 demonstrates that, internationally, Israel has the highest rate of VC investments, at $0.6 \%$ of GDP, in the high-tech sector. Remarkably, this is $50 \%$ higher than the US, three times higher than the UK and considerably greater than Germany or Japan. 
- Insert Fig. 1. about here please -

Fig. 1. International Venture Capital Investment in high-tech as a percentage of GDP, 1999-2002

As an indicator of the volume of investment in high-tech, figure 2 indicates an apparent return of investor confidence.

- Insert Fig. 2. about here please -

Fig. 2. Capital raised by Israeli high-tech companies, 2000-2004

It is clear from the above that new high-tech firms play an important role in Israel. However, the nature of success, or indeed, even survival it is less clear for these companies working at the leading edge of change. This is the issue that this paper addresses. Based on the experience and tacit knowledge of high-tech venture leaders, what are the critical factors for success?

\section{Research design and methodology}

Gartner et al. (1999) note that research on the efficacy of specific venture success criterion indicates a mixed set of results with few consistent findings. In addition, research on new venture success has tended to focus on evaluating the characteristics of a new venture opportunity at a particular point in time. Our approach was to try to capture how elements and process combine and thus to identify the critical factors. The study employed a multiple stage methodology as described in the following: 
Step discussions Model validation by Delphi review

Literature Review Final Model
Identification of the main topics and process factors influencing high-tech start-up success.

Develop the literature findings with respondents' contextualised practical experience.

Construction of a preliminary questionnaire. Test and revision of the survey instrument.

Data analysed from resulting open and closed responses.

Experts reviewed and refined the emergent model to Endorse the model and factor ranking.
Summary, conclusion and recommendations.

The first stage, the literature review identified a number of variables which influence the success of high-tech start-up companies; some were generic, whilst some are unique to Israel. These were then categorised and their roles and parameters noted. The second phase involved 13 in-depth personal interviews with recognized leaders in the high-tech start-up community, this reflected Yin's (2003) point that interviews are the preferred strategy when "how" or "why" questions are posed within a real-life context (Yin, 2003). The respondents were leading managers of start-ups, engaged in different fields of activity and at different company life cycle stages. We also interviewed angel and VC investors involved in several start-ups. The purpose was to reflect upon different aspects of the authentic start-up environment as experienced.

The sample included managers and investors of/in: 
- Three companies originally considered to be very promising ventures, valued at more than $\$ 100$ million at their peak, but now closed;

- Three ventures currently in operation (i.e. existing for more than six years) and hoping to prosper in the near future;

- One enterprise focusing on a small niche market, striving for profits but with no plans or realistic opportunity for fast growth in the near future;

- Three ventures which have been sold, one to a big Israeli company, one to a foreign company and a third to a US organization;

- Two investors interviewed belong to two of the leading VC houses in Israel and an angel who has invested tens of million dollars in high-tech start-up ventures.

In addition, data was collected by analyzing observations of senior individuals actively involved in the high-tech start-up community; follow up of local newspapers and participating in professional workshops and seminars dealing with high-tech. From these various observations, our provisional working model was constructed.

Thereafter we operationalised the provisional model into a survey instrument. We applied this as a preliminary questionnaire pilot survey at face to face interviews with respondents from twelve diverse start-up and experts. The purpose of the pilot was to refine our instrument; overcome any lack of clarity and ambiguity; establish reliability and discover any missing issues. The questionnaire was tested for consistency (Cronbach $\alpha$ ) and was modified to achieve the final questionnaire version.

The final questionnaire included 42 closed questions and many open ended questions intended to tap into different types of responses to enquire about issues not suited to 
closed questions or to identify items that we had not anticipated. Because of the history of poor response rates by senior respondents, the final questionnaires were distributed to personal contacts and with the assistance of organizations such as the Israeli Center of Management, MATI - the Israeli Institute Fostering Entrepreneurship, ISEMI - The Institute for the Study of Entrepreneurship and Management of Innovation, RDC Rafael Development Corporation and some friends. $80 \%$ of the responses came from or through personal contacts. The response rate of the population contacted by the organizations was much lower, but cannot be precisely reported. In total, the survey was completed by the CEOs or VPs of 70 high-technology start-up companies and by 10 Venture Capitalists or consultants.

The data were first analyzed qualitatively to investigate any unanticipated elements or patterns. This was followed by a statistical analysis of the findings, to establish a ranking of the topics and the major elements within each topic which were deemed critical and those seen as less important. The final step was validation of the model by the Delphi method, where half of our respondents were asked to consider the model and rank it again. The Delphi Methods use of a panel of experts proposes that the group will converge toward the "best" response through this consensus process (Linstone and Turoff, 1975). The midpoint of responses is statistically categorized by the median score. Our response rate for the final stage was $40 \%$, with a total of 16 verifying responses. 


\section{Factors in high-tech start-up success}

In practice, most new ventures are better characterised by directed chaos than orderliness. However, to develop a conceptual viewpoint we need to establish a theoretical framework which articulates the formative dimensions of a new high-tech venture. Thus, the purpose of this section is to review the literature to identify the conceptual categories considered important to new ventures. Interestingly, Cunningham (2000) asserts that more failures in high-tech can be attributed to business reasons rather than reasons associated with the technology. However, studies (Cooper, GimenoGascon, and Woo, 1994; Dahlquist et al., 2000) suggest that there is no single dominant factor influencing the venture's destiny and that several dimensions shape the probability of success. Bell and McNamara (1991) describe the Bell Mason model which identifies four major fields and includes twelve distinctive dimensions.

\begin{tabular}{|c|c|c|c|}
\hline Technology Product & Marketing/Sales & People & Finance/Control \\
\hline Technology/Engineering & Business Plan & CEO & Operations/Control \\
$($ R\&D) & & & \\
\hline Product & Marketing & Team & Finance-ability \\
\hline Manufacturing & Sales & Board of & Cash \\
& & Directors & \\
\hline
\end{tabular}

The Bell Mason dimensions for start-up assessment

Similarly, Macmillan et al. (1987) identify four dimensions; the entrepreneur, the product, markets and finance. Kakati (2003:447), critical of the poor predictive power of existing models, adds two additional elements, resource based capability and competitive strategy. Cooper et al. (1994) take a slightly different approach and specify 
four groups as predictors of new venture performance; general human capital, management know-how, industry-specific know-how and financial capital. Davidson and Klofsten (2003) describe a business platform of eight firm-level cornerstones; the business idea, the product, the market, the organization, core group expertise, core group drive/motivation, customer relations, and other relations. They explain that the cornerstones can be divided into the development process (idea, product, market, and organization), key persons (Founder, CEO, Board of directors - expertise and motivation) and the flow of external resources (customer and other firm relations). The process emphasis in Davidson and Klofsten's work, which was tested on young hightech ventures, seems to capture the inter-dynamic nature of the new venture creation rather better than a static list of elements. In summary, the literature indicates six distinctive domains of new high-tech ventures; entrepreneurship, strategy, marketing, technology and products, management, finance and control. To this we must add the impact of the external environment.

\section{The role of factors in high-tech success}

\section{The Entrepreneur}

Roberts (1991) describes the entrepreneurial role and function as the application of innovation. Oakey (2003) points out that the technical entrepreneur is the acknowledged key catalyst. Kakati (2003) finds, counter to Sandberg and Hofer's view (1987), that entrepreneurial quality plays a critical role in the gathering and application of resources. Indeed, as Oakey (2003:679) notes, whilst technical ability may be necessary, sufficiency to ensure success "lies in an ability to develop additional management skills to exploit such expertise". Moreover, Oakey and Mukhar (1999) and 
Oakey (1995) propose that as well as intimate technical knowledge, entrepreneurs should have a deep belief in market potential. Thus the entrepreneurial role is an amalgam of technical knowledge, managerial capability and something akin to passion.

\section{Strategy}

Bantel (1998), noting the contribution of technology based adolescent firms, argues that their strategies, aligning the firm's strengths and weaknesses with the environment, are critical for long term viability. Strategy's goals are to achieve advantage for the organization through configuration of resources within a demanding environment and is thus (Johnson and Scholes, 2001), the long term direction and scope of the organization. There are two schools which advocate different start-up strategies to gain competitive advantage; the formal strategy led by frameworks such as Porter's (1980) 'Five Forces' model, analyzing the forces driving industry competition; and the adaptive 'visionary' approach, proposed by Mintzberg (1994), whereby the organization is run according to a mission, and decisions are reached through learning and experience and are based on the intuition and creativity of key personnel.

One of management's most critical strategic choices is whether to compete broadly across many geographic segments or, alternately, to focus on a more limited set of geographic markets. Some researchers suggest a broad strategy for high growth markets and focused strategy whilst penetrating a mature market, whilst others advocate focusing in the early stage of products. Several recent studies (Chandler and Hanks, 1994; Mahoney and Pandian, 1992) describe the importance of multiple strategies. Kakati (2003) argued that multiple strategies are the logical choice, provided the firm acquires multiple resources. However, since most small start-up ventures find it 
difficult to develop multiple resources to successfully implement broad strategies, the natural choice is to pursue a focus/customized strategy.

\section{Marketing}

Gardner et al. (2000) identify unique characteristics of the high-tech market environment; earlier stage of the industry life cycle, greater degree of turbulence, higher product differentiation, higher market growth rate, shorter expected life cycle, more visible future for technology, easier entry into the market, more diverse suppliers and a higher level of consumer involvement in purchase decisions. Given the small size of Israel's domestic market, firms typically need to penetrate foreign markets. Indeed, Frenkel et al. (1994), Steinberg, (1999) and Goldman, (2001) all emphasize access to overseas markets as essential for the survival of a start-up enterprise. Recent developments in the marketing literature provide an interesting insight into the entrepreneurial process. Market-driven capability, referred to as "market orientation" is defined as a systemic process of tracking trends and recognising opportunities in the marketplace by utilizing intelligence generation and information dissemination activities (Day, 1999; Jaworski and Kohli, 1993; Slater and Narver, 1999). Cooper (1994) identifies strong market orientation - a market driven and customer focused New Product Process is a key success factor for new products. Market-oriented businesses usually seek to understand customers' expressed and latent needs and develop superior solutions to meet them (Kohli and Jaworski, 1990; Slater and Narver, 1995). Christensen and Bower (1996) claim that firms with a strong market orientation may over-emphasize current customer needs, possibly overlooking future products and growth opportunities but other researchers, such as Slater and Narver (1998) disagree. 
There is also disagreement amongst scholars about the importance of market attractiveness. Nesheim (1997) holds that the target market should be large and rapidly expanding, so the venture should consider market size, intensity of competition, revenue (and margins) potential over five years and potential customers. Mishra et al. (1996) and found that markets growth and size are often highly positively correlated with new product success. But conversely, Stuart and Abetti (1987) found a strong negative correlation between success in young technological companies and market attractiveness. Their study shows that companies entering smaller and slowly growing markets were doing better than those in the larger faster growing markets. This may be due to lower level of competitiveness and the avoidance of head on competition with large and strong organisations. Nonetheless, there is broad agreement that expertise in marketing activity and marketing effectiveness of the new product diffusion are critical for new products success (Cooper and Kleinschmidt, 1990; Gardner et. al., 2000).

Cooper $(1979,1994)$ stresses product uniqueness and superiority; products which are highly innovative and new to the market. Thus revolutionary breakthrough ideas have a particular advantage; they are clearly differentiated and have high barriers for competitors. However, it is also harder to demonstrate market potential and provide evidence for sustainable profits (Christensen, 1997). The assessment of new "yet to be born" product's markets potential is difficult; market research may indicate little interest (potential) at this stage. Perlmuter (2003) argues that leaders and managers have to understand the markets and their limits and channel their creativity to solutions that provide the customer with the complete product. 


\section{Technology and product}

Great "devices" are invented in the laboratory, but great "products" are invented in the marketing department (Davidow, 1986). Cooper (1993) found that the product must thus meet a market need. Development of new technology (Berry, 1996), or being first to market Cooper (1979), does not determine success. The issue of what the market wants and needs thus requires a combination of marketing and technical skills. Moreover, the importance of buyer/seller relationships, particularly in improving the new product development process, is a growing area of study (Birou and Fawcett, 1994). Roberts (1987), Wind and Mahajan (1988), Erickson et al. (1990) argue that strong links between the $\mathrm{R} \& \mathrm{D}$ department and other functional areas emphasize the importance of effective integration of $\mathrm{R} \& \mathrm{D}$ and marketing for innovation success. Goupta and Wilemon (1990) describe the relationship between R\&D and marketing as one aimed at succeeding in product innovation. Young (1973) and Souder $(1977,1981)$ note that the failure to integrate $R \& D$ and marketing early in the innovation process is one of the biggest contributors to new product failure. Thus technology strategy has to be integrated into overall corporate strategy (Erickson et al., 1990; Green, 1995).

\section{Management}

High-tech is an evolutionary and fast moving environment and corporate survival depends upon successfully managing that evolution (Leonard-Barton,1992). The pace of environmental change requires start-ups to be managed, not only by skilled managers, but also by a team capable of managing changing markets (Eisenhardt and Brown, 1998). Roure and Maidique (1986) demonstrate that founders of successful high-tech ventures tend to form larger, more complete teams. Thus a diversified management team, in which technological expertise coexists with business skills in other key areas such as marketing and finance, is recognized as a deciding factor for 
success in high-tech start-ups (Roberts, 1968, Cooper 1973). High performance new firms are rarely started by individuals; $80 \%$ are established by teams (Reynolds, 1993). Chandler and Hanks (1998) and Roure and Keely (1990) find that team completeness and previous joint experience were strongly associated with firm performance.

\section{Finance}

Most high-tech start-ups raise seed funding then raise additional rounds of capital until exit or acquisition; most successful high-tech start-ups eventually become public or are procured by a bigger company. Funding is thus the oxygen of start-ups. Lerner and Avrahami (2002) found high availability of funding for new entrepreneurship in Israel and that venture capital is a major source. One difficulty noted was the reduction of government guarantees to new entrepreneurs. However, after the NASDAQ collapse in 2000 there was a substantial decrease in foreign investment in Israel, but by 2004 the uptrend returned to VC funds' inflow to the high-tech sector.

Several studies have reported important value added benefits provided by venture capitalists. These benefits include help in obtaining additional financing, improving investment decisions and providing non-financial assistance such as strategic planning and help in recruiting key executives (MacMillan et al., 1989; Gorman and Sahlman, 1989; Sapienza, 1992; Goupta and Sapienza, 1992; Sapienza et al., 1996; Hellman and Puri, 2001). Recent research on the VC investment decision process suggests that VCs lack a strong understanding of how they make decisions. In addition to a lack of introspection, $\mathrm{VCs}$ are overconfident in their decision process and this negatively affects VC decision accuracy (Zacharakis and Shepherd, 2001). Moreover, Israeli VCs and their allies, the US investment bankers, claims Bainerman (2002), are solely 
concerned with quick exits and not with the once noble concept of building enterprises for the long term and for the benefit of the entire country.

\section{External Environment}

Specht (1993) classifies five main environmental factors affecting organization formation; the social aspect - impact of networks, cultural acceptance; economy capital availability, aggregate economic factors and unemployment; political - support of public or semi public agencies; infrastructure development - several aspects such as the education system, the nature of the local labor market, incubator organizations, information accessibility and availability of premises; and market emergence integrates concepts of niche emergence and technological innovation.

Perlmuter (2003) claims the best solution for preserving high-tech competitiveness is a strong education system providing broad knowledge. In Israel the Defense Force (IDF) has special education programs such as Talpiot and Psagot to provide selected highly talented youngster with a high level technological education. Many high-tech start-ups include graduates of these programs and graduates of the IDFs special technology units. Moreover, some of the most successful high-tech start-ups stemmed from entrepreneurs formerly employed by the defense industry utilizing knowledge acquired in those organisations.

\section{Refining the literature}

Our next step was to develop the factors identified in the literature review with the experiences of 13 recognised leaders of the high-tech community. We wanted to ensure that we had covered all relevant topics and that we had fully understood the role of the 
factors identified. Our respondents made a number of observations which we captured and operationalised in the final survey instrument. These are paraphrased below:

1. Strategy was emphasised as driving the course of the organization. Thus the business plan has to be clear and based on realistic market needs. A major fault in many startups is a focus on technology.

2. Core Team expertise, diversified knowledge and harmony are essential for success. Many angels and VCs highlighted the assessment of the core team in investment decision making. Very often start-ups are founded by young people who themselves lack management skills and experience but don't hire suitable managers. This creates difficulties in both $\mathrm{R} \& \mathrm{D}$ and marketing processes. At certain stages, consultants can be useful where the start-up has a lack of expertise.

3. Personnel should be selected very carefully, because of the organisation's size; almost every employee has a major effect on the accomplishments of the start-up.

4. The "Bubble" period created a surplus of "hot" venture capital funds which had to be invested urgently, creating a shortage of professionalism amongst the investors. Thus investors, who were directors, often lacked the competence to assist the startup.

5. Most start-ups stem from engineers and scientists who often believe, erroneously, that a good product will sell. Marketing is not always seen as a profession and founders, inexperienced in marketing, may take on the role. Marketing departments are established very late (often too late) and are frequently treated as an area for making savings. There is a strong need to treat marketing as a critical field. The best professionals should know the market; select the correct market niche, and 
continuously update the marketing strategy. Products that need to educate the market should be avoided because this is a lengthy and resource demanding process. Marketers should be close to customers, understand their needs and implement their feedback.

6. The product should provide a complete solution (if not sold to OEM) and has to meet real needs and provide good quality. A product that can be easily adapted to different needs (reflecting geographical, climate or cultural differences) is a big advantage. A focus on a product or product family is critical to avoid wasting resources.

7. $R \& D$ should take advantage of the unique technologies existing in Israel and the skilled workforce available in the market. Communication between R\&D and marketing should be monitored and fostered.

8. Strategic alliances with key customers, other companies or marketing organizations are often the key for success. They can assist in R\&D and can bring the complete solution to the market in the right time and with the appropriate means. Securing alliances or cooperation at an early stage is a major benefit for a young venture.

9. Funding has to be timed correctly, especially because of the variability of availability, caused by fluctuations in the local and global economy.

10. Investors do not always add value. Instead of assisting in strategy, direction and opening the markets, they can become an obstacle. 


\section{Findings}

\section{Ranking of topics importance}

In the questionnaire we first asked our respondents (in part 1) to rank each of the 15 topics and its associated parameters on a Likert scale of 1-7, where 7 was most important. Respondents were also asked questions about details of the topics and to discover any additional issues. Table 1 presents the findings of the ranking. The data confirm that our list of "important" topics was correct; no category (subject) was ranked, in aggregate, lower than 4.2. Perhaps the most revealing aspect of the data in this part was the high ranking placed on the team. Team Commitment was ranked highest at 6.47 , with a SD of less than 1.00 and team expertise was ranked $4^{\text {th }}$ at 6.13 . Other topics identified as highly important were Marketing 6.17; Customer Relationships 6.15; Core Team Expertise 6.13 and Management, 6.05. Strategy 6.0, R\&D 5.95 and Idea 5.89 complete the list of the top eight topics which formed the group of high effect factors on start-ups success. The following seven topics, starting with Networking at 5.46, were ranked much lower and are perceived to belong to the second group, deemed to have a relatively lower impact. Thus the team's characteristics appear in this part to be the most important set of factors for high-tech start-up success.

\section{- Insert Table 1 about here please -}

Table 1: Ranking of the importance of the topics 
We were interested to note that the complete solution was ranked as considerably less important than the human elements. Surprisingly, funding type was not seen as critical. This may reflect the unique Israeli position in which the high involvement of VCs in high-tech start-ups generated disappointment because of the poor added value of the VCs'. Both the general environment and the political situation were not highly rated, but the economic situation was seen as of some importance. Thus, in many ways we see confirmation of the literature, that a good team will be successful and that the actual product is less critical. Moreover the data suggest that a good team will succeed, even in poor economic, environmental and political circumstances.

To obtain better discrimination between topics we then (in part 2 of the survey) asked respondents to focus on ranking the topics. They were asked to classify the topics into one of three groups, very important, important and less important and afterwards to rank the topics within each group. This provided us with the possibility to establish an overall rating of 1 (the most important topic) to 15 (lowest importance) for each of the topics. The final part of our study involved asking half of our respondents to comment on the results of the general survey (Delphi method). The results of the Delphi process are depicted in figure 3 . The box shows the answers in the $2^{\text {nd }}$ and $3^{\text {rd }}$ quartiles and the bold line is the median of the results. The Delphi results again emphasise two distinct groups; the first containing the seven topics with high importance and the second with seven topics perceived as having lower effect with development (R\&D) providing a buffer between the two groups with strong indications it belongs to the first group. Whilst we acknowledge that the Delphi method does have the effect of averaging responses, it also lends support, as expert confirmation, of the critical importance of the top rated factors. 
- Insert Fig. 3. about here please -

\section{Fig. 3. Delphi ranking of the validity of responses}

Figure 4 is a summary of the rankings and compares the three different forms of ranking; the overall ranking in part 2 , the ranking by critical group in part 2 , and the outcome of the Delphi ranking.

Whilst it illustrates minor disagreement about the relative ranking of the critical components, it demonstrates a broad trend of agreement about the importance of the different topic areas. The primary group consists of 8 topics deemed of highest importance and 7 topics of the secondary group with a lower impact are clearly delineated. Both groups include the topics identified in part 1 of the questionnaire. In part 2 and the Delphi ranking, there are five topics which are deemed to be very important and are ranked at the top. This implies that all features associated with the core team (commitment and expertise), the idea, strategy and marketing are considered critical for the new high-tech venture. Customer relationship, management and R\&D also belong to the high impact group. Less important topics are networking, funding type, the economy, the complete product and the organization, while the external factors of general environment and political situation are ranked at the bottom (as in part 1) and apparently have the lowest influence on the fate of the start-up.

\section{- Insert Fig. 4. about here please -}

\section{Fig. 4. The respondents ranking of the topics}

In the ranking of part 2 and Delphi method, the idea and strategy were ranked much higher than in part 1 . Thus overall, the emphasis amongst the critical factors moved 
towards product and the strategy. We can only speculate about the different rankings. However, it does seem possible that when forced to consider the relative importance of each topic, the objective of part 2, our respondents, recognised that without a good idea and a decent strategy to make it work, the other elements became secondary. In the first section, where respondents rated each topic individually, the importance of the team, may have been prioritised on some sort of tacit assumption that the idea had been reasonable to begin with.

\section{The Final model utilising the research results}

The survey and Delphi results provide us with some confidence that our list of factors identified from the literature represent the factors deemed important by experienced practitioners. Moreover, the general agreement about the critical factors demonstrates their significance. In this section we elaborate on these findings by incorporating the responses to the open ended questions.

The core team was identified as vital for success, thus both of the topics representing the core team; core team commitment and core team expertise were placed at the top of the list. The two major factors related to commitment; team motivation and association with the start-up goals were emphasised. High importance was assigned to leadership capability and the diversity of team experience. This suggests that the core team is possibly more important than any other topic. Many respondents claimed that with a strong and committed team the start-up will succeed. The market may shift, the strategy

could change, but ultimately people create success. Former experience was, surprisingly, ranked low. The investors' contribution was also evaluated as very low. 
This was probably an outcome of the general disappointment, commented upon in the interviews and open questions, about their investors' strategic or networking contribution.

The topic idea was also ranked very highly, as was the related subject, the necessity to meet customer needs, which appeared crucial to success in the market. Respondents commented that too many start-ups develop interesting products with innovative hightechnology but with no real market need. Sometimes a breakthrough technology may introduce a product too early for the market. Examples cited included many products launched in 2000 and 2001 intended for the third generation of cellular communications.

Strategy was considered as important, with an emphasis on future trend analysis and continuous updating. However, clear strategy at the outset and clear mission statement are not viewed as important. This was explained by noting how the typical start-up dynamic situation requires great flexibility in strategy formulation and adaptation. These data identified marketing as vital. Respondents allocated high importance to product perceived utility; comprehensive knowledge of the market; reliable marketing plan and the marketing and R\&D relationship. Supporting distribution channels did not receive a high score nor was the idea of creating new markets with new standards. Respondents suggested that educating the market is too costly.

Management capability and the team solidarity within the enterprise were observed as important, particularly with reference to "core team association with goals". 
Nonetheless, no priority was given to a specific management style and it was argued that management style should adapt to each individual venture.

Relationships with customers was cited as a key driver of sales. Almost all parameters related to this topic are considered to have high priority. Personal acquaintance with the targeted customers, understanding the customer's buying behavior, implementation of customers' feedback and market receptivity for the product were all noted. Only the parameter related to opportunities for continual sales was ranked with a somewhat lower importance. $R \& D$ was considered important, particularly in linking with the market. The quality of the $R \& D$ team and the product durability were seen as imperative. Networking in marketing (to open doors into the target market niche) and finance (to assist future fund raising) are perceived as very valuable.

The issue of a complete product is somewhat complex and might have been misunderstood by some respondents. Although a complete solution was not ranked very highly, responses recognised that the market seeks a complete solution. It was suggested that a possible reason is that many start-ups plan on selling directly to OEMs, (Original Equipment Manufacturers), which market the complete product/solution and others plan plan marketing alliances as a solution to address market needs.

The economy is not seen as a main factor in success, but the availability of funds was seen as related to the global economical situation. Most of the general environment parameters were ranked with low importance. However, many respondents noted that military service in Israel affects the capabilities of the young generation. Some of the 
skills gained during military service, such as improvisation skills were considered helpful in start-up regimes. Although the political situation and its parameters, the political environment and the security situation in Israel, had amongst the lowest rankings, this may be a result of misconception. Some respondents noted that start-up leaders may lack awareness and understanding of the real world behaviour, particularly when selling to large overseas organisation.

\section{The final model}

Figure 5 depicts our final model. The model highlights the topics deemed to be critical for success (the group of topics with highest importance) and describes some elements of successful process. As can be observed, the important topics namely, the idea; strategy; core team commitment; core team expertise; marketing; management; customer relations and $R \& D$ are relevant for start-ups in general. So although the data indicated that some factors were important in Israel these had a low ranking. For example, team solidarity is perceived as very strong in Israel due to the influence of the military service and possibly provides a unique advantage to Israeli start-up ventures; Availability of skilled work force - again a possible advantage for Israeli start-ups due to the high level of technological education and the large influx of educated and skilled immigration from Russia during the 1990s. Penetration of the international market scored relatively highly, but is true for any start-up which has a limited domestic market. The global economy has a general influence on the willingness to buy new products in general and from small and distant start-up in particular, but has also a strong influence on the availability of Venture Capital funds which play a major role in financing Israeli high-tech start-ups. 


\section{- Insert Fig. 5. about here please -}

\section{Fig. 5 . The Final Model}

\section{Conclusions}

The attempt to establish a practical model of critical success factors for application by nascent, emergent and growing companies in the high-tech sector appears to have been successful. The data shows a high level of consistency and reliability and demonstrated two categories of topics; those of the highest importance and those ranked less critical. The first group included, the commitment of the core team, their expertise, the idea itself, strategy in general and marketing strategies; customer relationships, management and $R \& D$ capacity. Those less critical were seen as networking, type of funding, the economy, a complete product, organization, the general environment and politics.

We do not propose that the study represents an entirely inclusive picture of new venture performance because there are always variables which may have been omitted. We do suggest that our new model contains a more comprehensive approach than previously considered. Although the model has reliability and validity, detailed enhancement could improve the practical utility. Further research on larger and broader samples in different environments, cultures and industries may yield a model with broader applicability. The final model we envision should have a multi dimensional matrix specifying the detailed description of the necessary elements in each topic and the desired level of achievement depending on variables such as the: different stages of the company life cycle, industry, and geographic region. 
Our model of the factors for success is derived from the extensive experience of many of leading Israeli experts. In consequence, it is soundly grounded in experience and knowledge and should have a very practical utility. The application of the model may enable new firms to identify and assess their capacities and thus to change, modify, amend or to acquire capacity to improve success rates. Whilst the model is based on the Israeli environment and experience, many other countries geographically distant from their main markets share many of these characteristics, so the model may have general utility. The model has still to be tested for causality, but could be adapted and expanded, hence it provides ample opportunities for future research. 


\section{References}

Azulay I., Lerner, M., Tishler A., 2000. Converting military technology through corporate entrepreneurship. The Israel Institute of Business Research.

Bainerman, J., 2002. Broken promises - the rise and fall of Israel's technology based industries. P.O.B. 387 Zichron Yaacov, Israel, 30900. (Unpublished).

Bell, G., McNamara, J., 1991. High-tech ventures - The guide for entrepreneurial success. Addison-Wesley, MA.

Bantel, K.A., 1998. Technology-based, "adolescent" firm configurations: strategy identification, context and performance. Journal of Business Venturing 13 (3), 205230.

Berry, M.M.J., 1996. Technical entrepreneurship, strategic awareness and corporate transformation in small high-tech firms. Technovation 16 (9), 487-498.

Birou, L.M., Fawcett, S.E., 1994. Global supplier involvement in integrated product development: a comparison of U.S. and European practices. International Journal of Physical Distribution and Logistics Management 24 (5), 4-14.

Business Week, 1997.

http://www.webteck.com/sites/businessweek/country/israel/home.htm

Chandler, G.N., Hanks, S.H., 1994. Market attractiveness resource-based capabilities, venture strategies, and venture performance. Journal of Business Venturing 9 (4), 331-349.

Chandler, G.N., Hanks, S.H., 1998. An investigation of new venture teams in emerging businesses. Frontiers of entrepreneurship research. Wellesley, Babson College, MA.

Christensen, C.M., 1997. The innovator's dilemma: when technologies cause great firms to fail. Harvard Business School Press, Boston, MA.

Christensen, C.M., Bower, J.L., 1996. Customer power, strategic investment, and the failure of leading firms. Strategic Management Journal 17 (3), 197-218.

Cohen, N., 2005. Israeli High-Tech Industry: 50 years of excellence. http://www.jewishvirtuallibrary.org/jsource/Economy/idc.html.

Cooper, R.G., 1973. Technical entrepreneurship: what do we know? R\&D Management $3(2), 59-64$.

Cooper, R.G., 1979. The dimension of industrial new product success and failure. Journal of Marketing 43 (3), 93-103.

Cooper, R.G., 1993. Winning at new products: accelerating the process from idea to launch. Addison-Wesley, Reading, MA. 
Cooper, R.G., 1994. New products: the factors that drive success. International Marketing Review 11 (1), 60-76.

Cooper, A.C., Gimeno-Gascon, F .J., Woo, C.Y., 1994. Initial human and financial capital as predictors of new venture performance. Journal of Business Venturing 9 (5), 371 - 395.

Cooper, R.G., Kleinschmidt, E.J., 1990. New product success factors: a comparison on "kills" versus successes and failures. R\&D Management 20 (1), 47-63.

Covin, J.G., Slevin, D., 1991. A conceptual model of entrepreneurship as firm behavior. Entrepreneurship Theory and Practice 16 (1), 7-25.

Cunningham, C., 2000. Technology Diaspora: Israeli high-tech industry faces a modern day exodus. Red Herring, Special Report on Israel 82, 252-257.

Dahlquist, J., Davidson, P., Wilkund, J., 2000. Initial conditions as predictors of New Venture Performance: A replication and extension of the Cooper et al. study. Enterprise \& Innovation Management Studies 1 (1), 1-17.

Davidow, W., 1986. Marketing high-technology. The Free Press, New York, NY.

Davidson, P., Klofsten, M., 2003. The Business Platform: developing and instrument to gauge and to assist the development of young firms. Journal of Small Business Management 41 (1), 1-26.

Day, G.S., 1999. Creating a market-driven organization. Sloan Management Review 41 (1), 11-22.

Dvir, D., Tishler A., 1999. The changing role of the defense industry in technologicalindustrial development in Israel. The Israel Institute of Business Research, Tel Aviv. (In Hebrew).

Eisenhardt, K.M., Brown, S.L., 1998. Time pacing: competing in markets that won't stand still. Harvard Business Review 76 (2), 59-69.

Erickson, T.J., Magee, J.F., Rousel, P.A., Saad, K.N., 1990. Managing technology as a business strategy. Sloan Management Review 31 (3), 73-78.

Frenkel, A., Reiss, T., Maital, S., Koschatzky K., Grupp, H., 1994. Technometric evaluation and technology policy: the case of biodiagnostic kits. Research Policy 23 (3), 281-292.

Gardner, D.M., Johnson, F., Moonkyu, L., Wilkinson, I., 2000. A contingency approach to marketing high-technology products. European Journal of Marketing 34 (9/10), 1053-1077.

Gartner, W.B., Starr, J.A., Bhat, S., 1999. Predicting new venture survival: an analysis of "Anatomy of a Start-Up." Cases from INC. Magazine. Journal of Business Venturing 14 (2), 215-232. 
Goldman, N., 2001. Israeli marketing: A work in progress. Israeli High-Tech Investor February, 44-45.

Gorman, M., Sahlman, W.A., 1989. What do venture capitalists do? Journal of Business Venturing 4 (4), 231-248.

Goupta, A.K., Sapienza, H.J., 1992. Determinants of venture capital firms' preferences regarding the industry diversity and geographic scope of their investments. Journal of Business Venturing 7 (5), 347-362.

Goupta, A.K., Wilemon, D., 1990. Improving R\&D - Marketing relations. R\&D Management 20 (4), 277-289.

Green, S.G., 1995. Top management support of R\&D projects: a strategic leadership perspective. IEEE Trans. Eng. Manage. 42 (3), 223-232.

Hellman, T., Puri, M., 2001. Venture capital and the professionalization of start-up firms: empirical evidence. Journal of Finance 57 (1), 169-197.

Israel Central Bureau of Statistics (ICBS),, 2001. Annual report. Government Publishing House, Jerusalem. (In Hebrew).

Israeli Ministry of finance - International Division., 2003. The Israeli economy at glance. http://www.mof.gov.il/beinle/ie/glance_eco2003.htm

Israeli Ministry of finance - Economic and Research Department., 2003. Economic outlook. http://www.mof.gov.il/research_e/eo03_03/mainpage.htm

IVC - Israel Venture Capital research center., 2004. Summary of Israeli high-tech company capital raising Q4 2004 and full year 2004. http://www.ivc-online.com

Jaworski, B. J., Kohli, A. K., 1993. Market orientation - antecedents and consequences. Journal of Marketing 57 (3), 53-70.

Johnson, G., Scholes, K., 2001. Exploring corporate strategy: text and cases, 6th ed. Prentice Hall, London.

Kakati, M., 2003. Success criteria in high-tech new ventures. Technovation 23 (5), 447457.

Kohli, A.K., Jaworski, B.J., 1990. Market orientation-the construct, research propositions, and managerial implications. Journal of Marketing 54 (2), 1-18.

Leonard-Barton, D., 1992. Core capabilities and core rigidness: A paradox in managing new product development. Strategic Management Journal, Summer Special Issue $13,111-125$.

Lerner, M. and Avrahami, Y., 1999. Global entrepreneurship monitor: Israel executive report. Tel Aviv University, Tel Aviv.

Lerner, M. and Avrahami, Y., 2002. Global entrepreneurship monitor: Israel executive report. Tel Aviv University, Tel Aviv. 
Linstone, H., Turoff, M., 1975. The Delphi method. Addison-Wesley, Reading, MA.

MacMillan, I.C., Zemann, L., Subbanarasimha., 1987. Criteria distinguishing successful from unsuccessful ventures in the venture screening process. Journal of Business Venturing 2 (2), 123-137.

MacMillan I.C., Kulow, D.M., Khoylian, R., 1989. Venture capitalists' involvement in their investments: Extent and performance. Journal of Business Venturing 4 (1) $27-47$.

Mahoney, J.T., Pandian, J.R., 1992. The resource-based view within the conversation of strategic management. Strategic Management Journal 13, 363-380.

Medcof, J.W., 1999. Identifying 'Super-Technology' industries. Research Technology Management 42 (1), 31-36.

Mintzberg, H., 1994. The rise and fall of strategic planning. Harvard Business Review $72(1), 107-114$.

Mishra, M., Kim, D., Lee, D.H., 1996. Factors affecting new product success: crosscountry comparisons. Journal of Product Innovation Management 13 (6), 530-550.

Nesheim, J., 1997. High-tech start-up. Nesheim, Saratoga, CA.

Oakey, R.P., 1995. High-technology small firms; variable barriers to growth. Paul Chapman Publishing, London

Oakey, R.P., 2003. Technical entrepreneurship in high-technology small firms: some observations on the implications for management. Technovation 23 (8), 679-688.

Oakey, R.P., Mukhtar, S.M., 1999. United Kingdom high-technology firms in theory and practice: a review of recent trends. International Journal of Small Business 17 (2), 48-64.

Oakey, R., Rothwell, R., Cooper, S., 1988. The management of innovation in hightechnology small firms-Innovation and regional development in Britain and the United States. Pinter, London.

Perlmuter, D., 2003. How to maintain competitiveness in high-tech. Haaretz newspaper 20.10. 2003 (in Hebrew).

Porter, M.E., 1980. Competitive strategy: Techniques for analyzing Industries and competitors. The Free Press, New York, NY.

Reeble, D., 1990. High-technology Industry. Geography 75, 361-364.

Reynolds, P., 1993. High performance entrepreneurship: what makes it different? Frontiers of Entrepreneurship Research. Wellesley, Babson College, MA.

Roberts, E.B., 1968. Entrepreneurship and technology: a basic study of innovators; how to keep and capitalize on their talents. Research Management 11 (4), 249-266. 
Roberts, E.B., 1987. Generating Technological Innovation. Oxford Univ. Press, New York.

Roberts, E.B., 1991. Strategic transformation and the success of high-technology companies. International Journal of Technology Management, Special Publication on the Role of Technology in Corporate Policy, 59-80.

Roure, J.B., Keely, R.H., 1990. Predictors of success in new technology-based ventures. Journal of Business Venturing 5 (4), 201-220.

Roure, J.B., Maidique, M.A., 1986. Linking pre-funding factors and high-technology venture success: an exploratory study. Journal of Business Venturing 1 (3), 295306.

Sandberg, W.R., Hofer, C.W., 1987. Improving new venture performance: the role of strategy, industry structure, and the entrepreneur. Journal of Business Venturing 2 (1), 5-28.

Sapienza, H.J., 1992. When do venture capitalists add value? Journal of Business Venturing 7 (1), 9-27.

Sapienza, H.J., Manigart, S., Vermeir, W., 1996. Venture capitalist governance and value added in four countries. Journal of Business Venturing 11 (6), 439-469.

Slater, S. F., Narver, J.C., 1995. Market orientation and the learning organization. Journal of Marketing 59 (3), 63-74.

Slater, S.F., Narver, J.C., 1998. Customer-led and market-oriented: let's not confuse the two. Strategic Management Journal 19 (10), 1001-1006.

Slater, S.F., Narver, J.C., 1999. Market-oriented is more than being customer-led. Strategic Management Journal 20 (12), 1165-1168.

Souder, W.E., 1977. An exploratory study of the coordinated mechanism between R\&D and marketing as an influence on the innovation process. Final Report to the National Science Foundation, University of Pittsburgh, School of Engineering, Pittsburgh, PA.

Souder, W.E., 1981. Disharmony between R\&D and marketing. Industrial Marketing Management 10 (1), 67-73.

Specht, P.H., 1993. Munificence and carrying capacity of the environment and organization formation. Entrepreneurship Theory and Practice 17 (2), 77-86.

Steinberg, J., 1999. Taking the long view. Israel high-tech Investor 5, 18-19.

Stuart, R., Abetti, P.A., 1987. Start-up venture: towards the prediction of initial success. Journal of Business Venturing 2 (3), 215-230.

Traston, I., Sarusi, Y., Kochavi, D., Zisapel J., Ayalon, E., 2002. The technology industry as a growth lever. Working paper for the Herzeliya Conference, December 2002. 
Wind, Y., Mahajan, V., 1988. New product development process: a perspective for reexamination. Journal of Production and Innovation Management 5 (4), 304-311.

Yin, K.R., 2003. Case study research, design and methods. SAGE Publications, London.

Young, H.C., 1973. Product development setting, information exchange and marketingR\&D coupling. Ph.D. dissertation. Northwestern University, Chicago, Ill.

Zacharakis, A.L., Shepherd, D.A., 2001. The nature of information and overconfidence on venture capitalists' decision making. Journal of Business Venturing 16 (4): 311332.

Schaul Chorev is a doctoral student at Pec's university in Hungary and is currently spending one year as a research fellow at the Centre for Entrepreneurship at Aberdeen Business School, Robert Gordon University. Schaul received his BSc degree in Electrical Engineering from the Technion in Haifa, Israel in 1979 and his MBA degree from the University of Oregon in 1990. He has a long international working experience in Israel and overseas as an electronic engineer and in marketing of high- tech systems. His current research interests are primarily related to high-tech entrepreneurship with focus on marketing and strategies of high- tech start-ups.

Alistair R Anderson, is Professor of Entrepreneurship and Director of the Centre for Entrepreneurship at Aberdeen Business School, Robert Gordon University in Aberdeen, Scotland. After some 20 years of starting and running small businesses, his curiosity about entrepreneurial people drove him to study entrepreneurship. Unfortunately he found that rather than answering his questions, he simply found more that there were many more interesting questions! He is still trying to answer some of them, especially in the social realms of entrepreneurship. Current themes being explored are social capital, social constructions and associated topic areas. 
Fig. 1. International Venture Capital Investment in high-tech as a percentage of GDP, 1999-2002

Source: Based on data from Israeli Export Institute

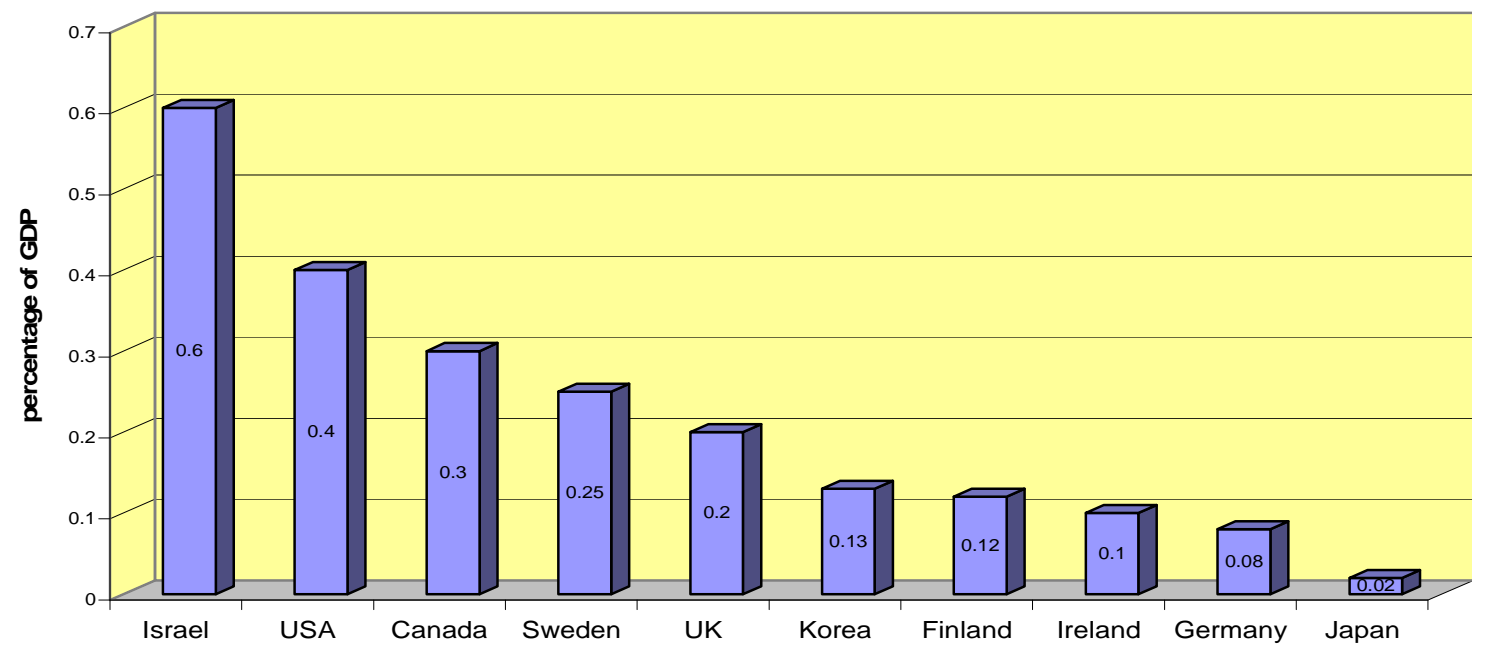

Fig. 2. Capital raised by Israeli high-tech companies, 2000-2004

Source: Based on data from Israeli Venture Capital (IVC) Research Centre

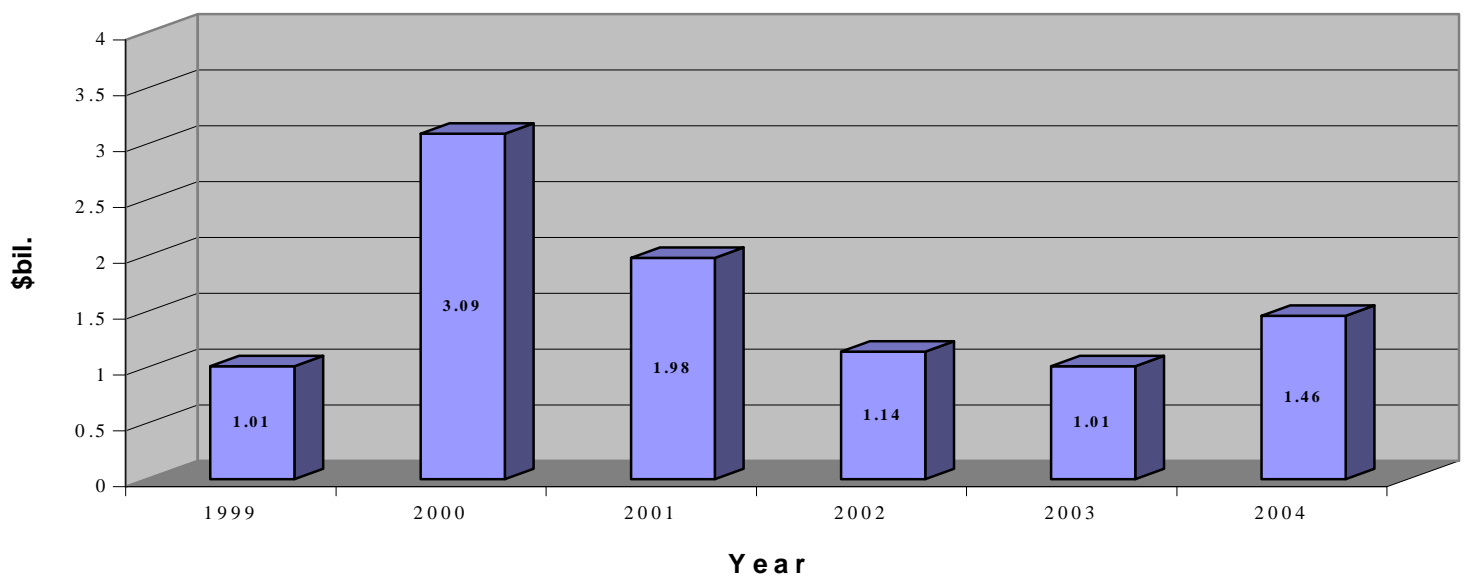


Fig. 3. Delphi ranking of the validity of responses

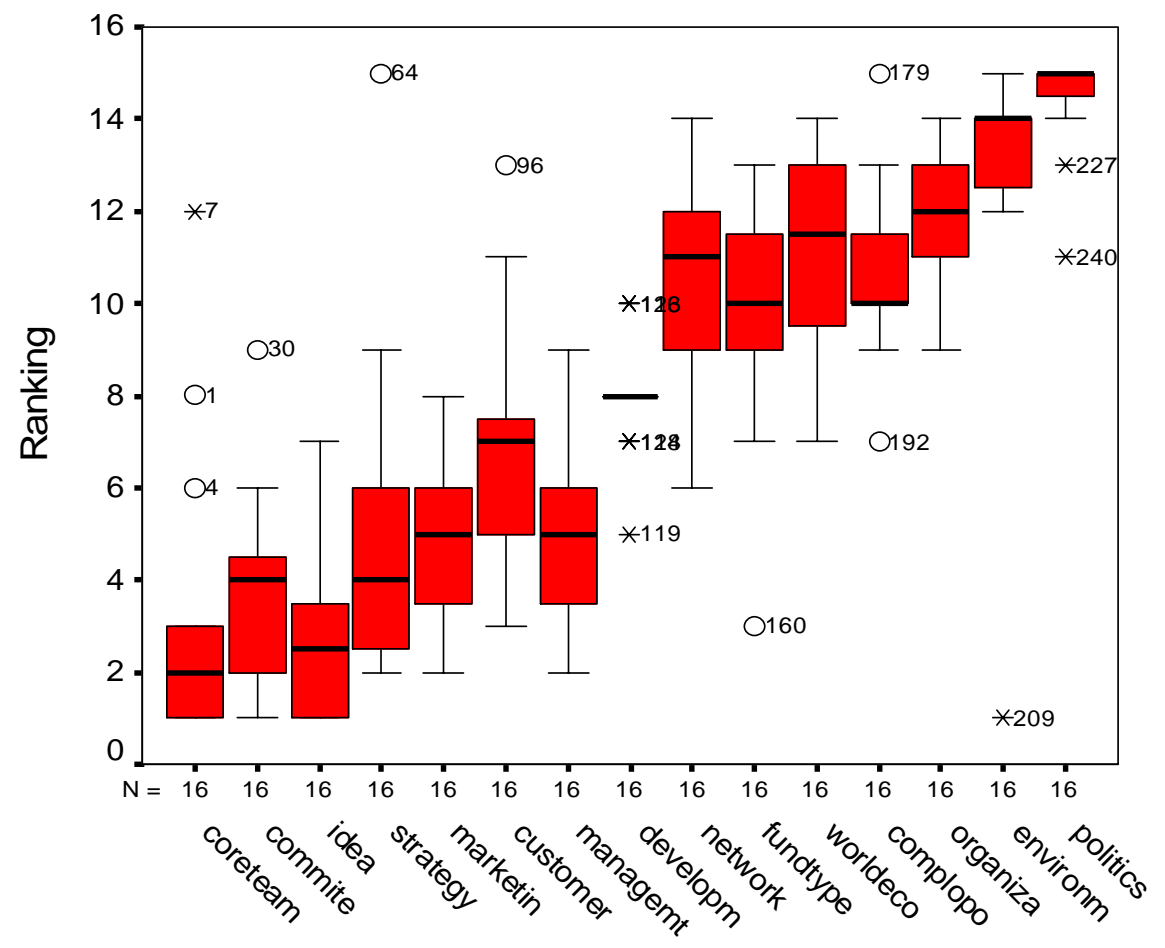

Fig. 4. The respondents ranking of the topics

\begin{tabular}{|cc|}
\hline$\square$ Part C & $\square C$-Groups \\
\hline
\end{tabular}

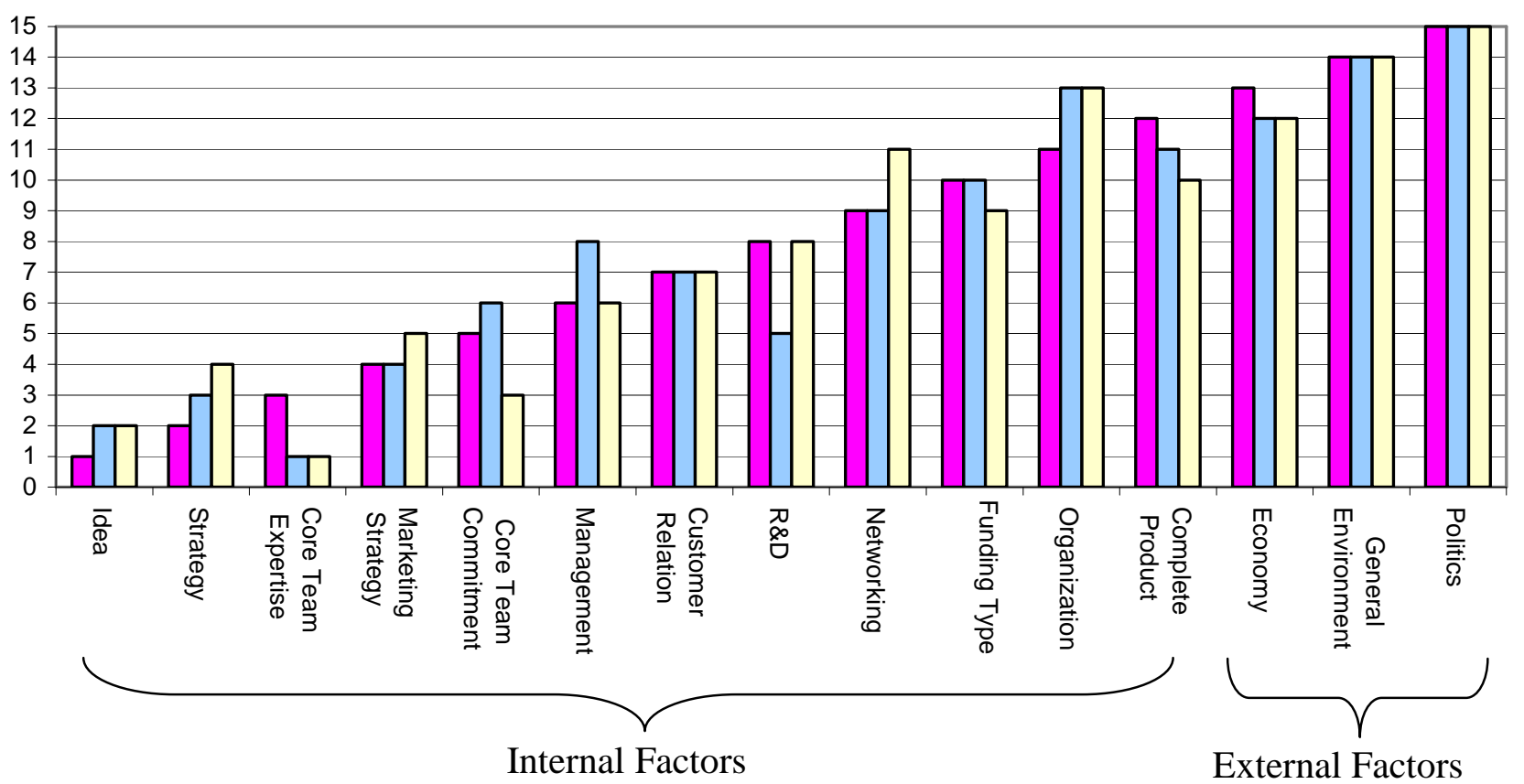


Fig. 5. The Final Model

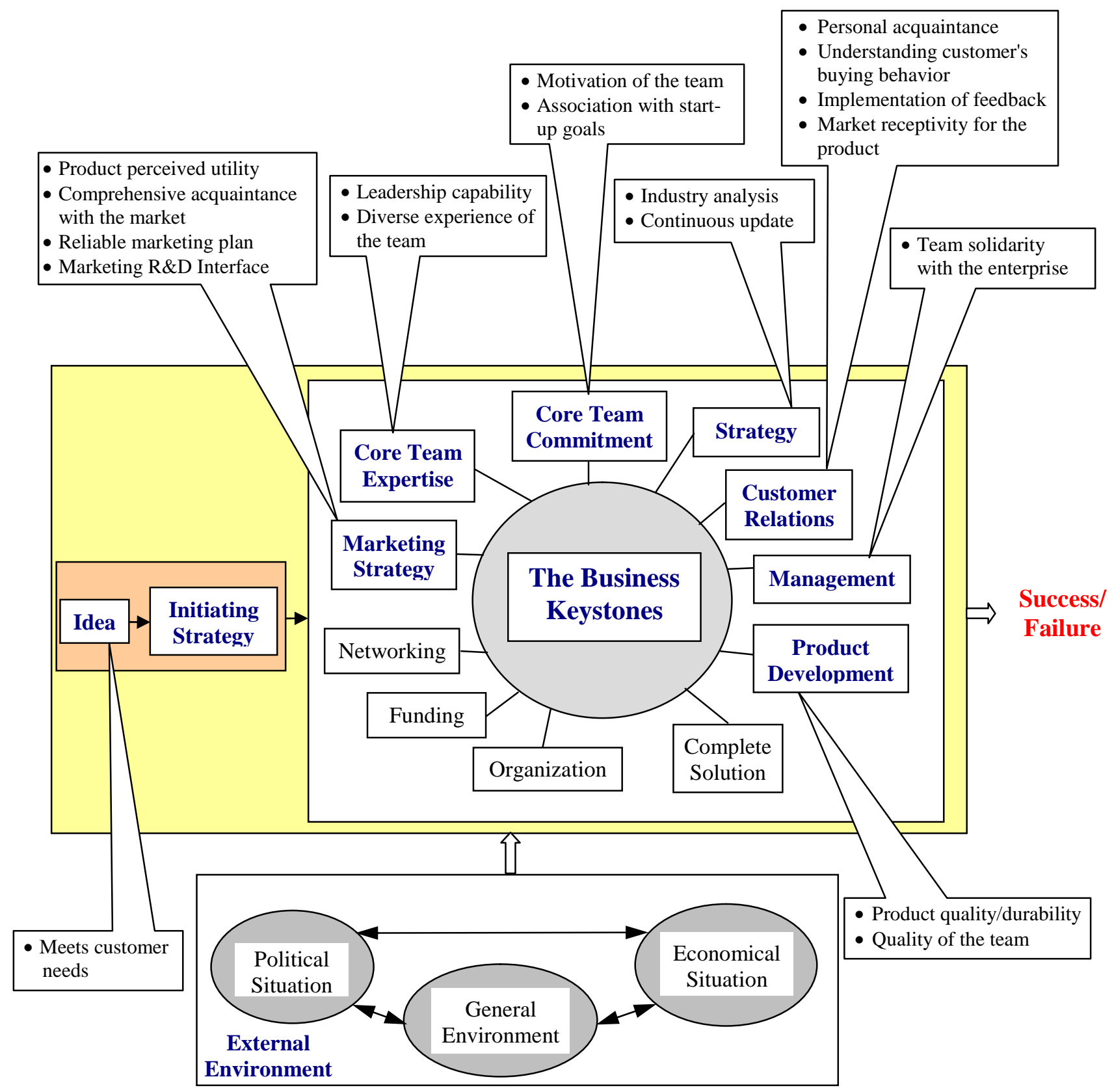


Table 1: Ranking of the importance of the topics

\begin{tabular}{|c|c|c|c|c|c|}
\hline & Mean & SD & & Mean & SD \\
\hline Idea & 5.89 & 1.240 & Strategy & 6.00 & 1.140 \\
\hline Idea formulation & 5.87 & 1.390 & Mission statement & 5.30 & 1.555 \\
\hline Idea meets customer needs & 6.27 & 1.136 & Industry analysis & 5.99 & 1.138 \\
\hline Core team expertise & 6.13 & 1.018 & Strategy clarity & 5.09 & 1.487 \\
\hline Team diversified experience & 5.95 & 1.142 & Strategy update & 5.82 & 1.295 \\
\hline Team former experience & 5.04 & 1.490 & Core team commitment & 6.47 & .936 \\
\hline Team leadership capacity & 6.32 & 1.183 & \begin{tabular}{|l}
$\begin{array}{l}\text { Core team association with } \\
\text { goals }\end{array}$ \\
\end{tabular} & 6.46 & .921 \\
\hline Consultants & 5.24 & 1.478 & Core team motivation & 6.58 & .919 \\
\hline Investors' contribution & 4.64 & 1.450 & Marketing strategy & 6.17 & 1.088 \\
\hline Organization & 4.95 & 1.327 & Market expertise & 6.03 & 1.240 \\
\hline $\begin{array}{l}\text { Employee definition of } \\
\text { responsibility domains }\end{array}$ & 5.08 & 1.238 & Marketing plan & 6.01 & 1.051 \\
\hline Few organizational levels & 5.19 & 1.368 & \begin{tabular}{|l|} 
Marketing research \\
\end{tabular} & 5.08 & 1.457 \\
\hline Customer Relationship & 6.15 & 1.110 & Market growth & 5.22 & 1.324 \\
\hline Customer needs & 6.15 & 1.167 & New market standards & 4.78 & 1.533 \\
\hline Customer buying behavior & 6.16 & 1.126 & \begin{tabular}{|l|} 
International market \\
penetration
\end{tabular} & 5.69 & 1.252 \\
\hline Feedback implementing & 6.15 & 1.167 & Market dynamics & 5.75 & 1.286 \\
\hline Market receptivity & 6.11 & 1.173 & Patents registration & 5.36 & 1.751 \\
\hline Continual sales & 5.53 & 1.588 & Perceived utility & 6.34 & 1.120 \\
\hline Management in general & 6.05 & 1.250 & Distribution channels & 4.63 & 1.538 \\
\hline Management style & 5.27 & 1.588 & Product positioning & 5.56 & 1.383 \\
\hline Team solidarity & 5.99 & 1.204 & Marketing R\&D relationship & 5.96 & 1.265 \\
\hline Employee development & 5.63 & 1.300 & Main market penetration & 5.92 & 1.285 \\
\hline Networking in general & 5.46 & 1.241 & R\&D capability & 25.95 & 1.038 \\
\hline Complete solution & $\overline{5.36}$ & 1.485 & \begin{tabular}{|l} 
Technological manpower \\
availability
\end{tabular} & 5.78 & 1.141 \\
\hline A gadget & 4.64 & 1.455 & \begin{tabular}{|l|}
$\begin{array}{l}\text { Defense technology and } \\
\text { infrastructure }\end{array}$ \\
\end{tabular} & 4.23 & 1.806 \\
\hline Complete product & 5.39 & 1.561 & Development team & 5.95 & 1.161 \\
\hline Cooperation in $\mathrm{R} \& \mathrm{D}$ & 5.31 & 1.528 & Innovation level & 5.70 & 1.358 \\
\hline Cooperation in marketing & 5.71 & 1.426 & \begin{tabular}{|l|} 
Technological breakthrough \\
\end{tabular} & 5.34 & 1.353 \\
\hline Funding Type & 5.31 & 1.303 & Easiness of adaptation & 5.55 & 1.341 \\
\hline Political situation & 4.34 & 1.553 & Product quality and durability & 6.12 & 1.256 \\
\hline Political environment & 4.39 & 1.658 & Product price & 5.71 & 1.346 \\
\hline Security situation & 4.26 & 1.708 & Time to market & 5.41 & 1.480 \\
\hline General Environment & 4.96 & 1.219 & Economic Situation & 5.43 & 1.271 \\
\hline Military service & 4.45 & 1.730 & Global economy & 5.63 & 1.340 \\
\hline Entrepreneurship education & 4.85 & 1.387 & Domestic economy & 4.79 & 1.586 \\
\hline $\begin{array}{l}\text { Availability of skilled } \\
\text { workforce }\end{array}$ & 5.64 & 1.259 & $\begin{array}{l}\text { Availability of financial } \\
\text { resources }\end{array}$ & 5.82 & 1.246 \\
\hline Government support & 4.89 & 1.420 & & & \\
\hline Cultural and social norms & 5.18 & 1.325 & & & \\
\hline
\end{tabular}


